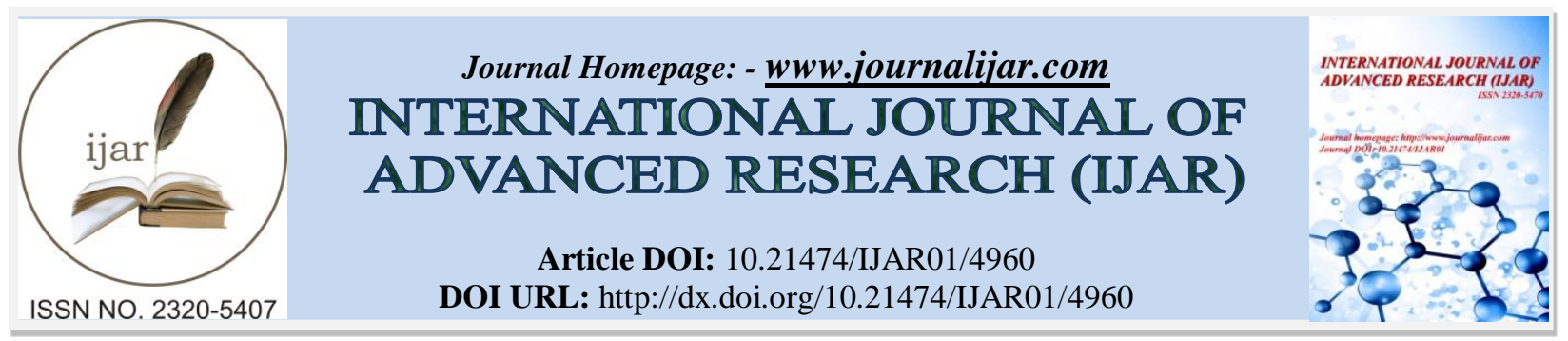

RESEARCH ARTICLE

\title{
RESOURCE BASED VIEW AS A STRENGTHENING OF INDUSTRY'S CAPABILITIES TO IMPROVE COMPETITIVE STRATEGIES.
}

Sri Sarjana, Dwi Kartini, Popy Rufaidah and Yunizar.

Doctoral Program in Business Management, Faculty of Economic and Business, Padjadjaran University, Indonesia.

\section{Manuscript Info}

Manuscript History

Received: 26 May 2017

Final Accepted: 28 June 2017

Published: July 2017

Key words:-

resource based view, human capital,

knowledge resources, competitive

strategy, competitive advantage

\section{Abstract}

Competitive advantage as the impact of the implementation company operation strategy in creating value creation on the products and services produced. Cost leadership and differentiation for products or services into a strategic part in achieving competitive advantage. Competitive strategy becomes part of the corporate strategy led to increased productivity and performance. Resource-Based View is a part of the company's capability in encouraging superior competing. This study empirically investigates whether there is an effect resources based view, competitive strategy and competitive advantage. The results showed that resources based view are effective and positive direct effect on competitive strategy. Competitive strategy has effective and positive direct effect on competitive advantage. Moreover, this study demonstrated that the effect of competitive advantage is mediated by competitive strategy. This finding integrates insights competitive strategy framework into a generalization of the competitive advantage in industries. Furthermore, this research is expected to support for industry have valuable suggestions to effectiveness in competitive strategy and achieved the company's goal especially in competitive advantage.

Copy Right, IJAR, 2017,. All rights reserved.

\section{Introduction:-}

The business activity is carried out in a dynamic environment and a lot of changes strategy, analyze the factors that might influence the competitive environment, it is in function of time. The strategy has a lot of predictive exercise and exercising in a long-term horizon (Contreras \& Silva, 2013). Business to business provides many growth opportunities and benefits for firms, such as cost reductions, efficiency improvements, better supplier relationships, access to global markets, new customers and suppliers, productivity improvements, increased profits, and gains in competitive advantage (Fauska et al., 2013). Strategy as a method of analysis that allows to know the general characteristics of a particular market and all the elements that come together for the purpose of gaining competitive advantage (Rocha, 1999). As today's dynamic and turbulent environment is maintained, the technical infrastructure as well as people's knowledge and experience in many different fields, intimate conversations in the hallways of most people and staff in their knowledge of their exchange after a period of time that may be desired are not achieved, and technical or administrative units or design engineers as well as experts in other units may solve a specific problem or issue in relation to the roles they have assumed (Kaveh et al., 2015). 
RBV view has been widely used and appreciated in strategic management of private organizations (SzymaniecMlicka, 2014). RBV emerged as an alternative to the strategic management theories explaining competitive advantage of an enterprise with its market position (Baumane-Vitolina \& Cals, 2013). Competitive advantage has important forces in the global industrial competition for survival and continuity (Angelmar, 1990). Firms may gain a sustainable competitive advantage if they choose the right innovation strategy (Kuratko et al., 2005). In today's highly competitive environment, to be successful and to achieve world class manufacturing so organizations must possess effective manufacturing strategies (Jain \& Ahuja, 2012). Function as organizational units for the integration of knowledge and innovative activities, providing continuous input for organizations involved in actual environmental protection work, and strengthening the effectiveness of the overall environmental protection system (Chao, 2014). Managers and entrepreneurs of organizations should identify the main and systematic variables affecting inside and outside of the organization. The company should act with flexibility and based on adoption of preventive strategies of business which include start-up and implementation processes of the period of organizational changes (Laursen, 2012). The purpose of this study is determined the influence of RBV, competitive strategy and competitive advantage, especially in the manufacturing industry. Analysis of the variables studied come from internal resources without involving external factors at industries.

\section{Literature Review:- \\ Resources Based View:-}

Particular resource to be the key consist of human capital, knowledge and leadership to success in a dynamic environment, one should instead focus more on promoting the approach of the resource based view in the organization as an effective strategy (Szymaniec-Mlicka, 2014). RBV of the firm suggest the family, widely defined to include that extended kinship group of cousins in-laws and relationships in local business community or religious groupings, the represent internal resources, capabilities and knowledge, which can leveraged to create, identify and exploit a business opportunity (Howorth et al., 2010). The RBV argues that valuable, rare, inimitable, and nonsubstitutable resources are the source of a firm's sustained competitive advantage (Cao et al., 2014). A compliment to this external view in the early stages of the strategic planning process is the RBV, which takes an internal orientation by systematically evaluating relevant organizational resources, which could present potential competitive advantages (Kash et al., 2014). RBV is one of the various conceptions for strategic management which makes an attempt to clarify the background of enterprise existence as well as its various occurrences in broader outlines of the theory of the firm (Baumane-Vitolina \& Cals, 2013).

Strategy of public organizations on the RBV will help them achieve success in a turbulent environment in the organization as an effective strategy (Szymaniec-Mlicka, 2014). The main resource categories in RBV consist of material resources included financials, buildings, equipment, technologies. Non material resource consists of brands, licenses, enterprise reputation, cooperation networks. Competences consist of knowledge, organizational abilities to use fixed assets, observed business opportunities, ability to produce new knowledge on old basis, ability to produce innovations (Baumane-Vitolina \& Cals, 2013). Kash et al., (2014) described dimension RBV consists of capital resources and human resources. The relevance of the RBV becomes apparent during resource deployment for strategy implementation.

\section{Human Capital:-}

Human capital is the employees' ability to do things that ultimately make the company works and succeeds (Jyotirmayee \& Mishra, 2010). Human capital refers to the knowledge, skills, and abilities embodied in people (Coff, 2002). The human capital can be defined as the stock of knowledge, skills, competencies, and abilities embodied in individuals that determine their level of productivity. In principle, it includes innate abilities, and skills acquired through education, training and experience (Jules \& Fondo, 2012). Human capital is important because it is a source of innovation and strategic renewal (Bontis, 1999). Human capital as the stock of accumulated knowledge, skills, experience, creativity and other relevant workforce attributes and suggest that human capital management involves putting into place the metrics to measure the value of these attributes and using that knowledge to effectively manage the organization (Angela \& Michael, 2007).

The human capital has been emphasized as one of the key success factors of a company. It can be assumed that most successful companies have organized or at least they should have organized their management of the human capital systematically (Souleh, 2014). Human capital comprises of the competence, skills, and intellectual ability of the individual employees (Marta-Christina, 2000). Human capital is the stock of competencies, knowledge and personality attributes embodied in the ability to perform labor, so as to produce economic value (Jules \& Fondo 
2012). The management of human capital can be put into practice by applying competence management and knowledge management practices. Human capital theorists have typically argued that organizations can increase their human capital by internally developing the knowledge and skills of their current employees, and by attracting individuals with high knowledge and skill levels from the external labor market (Souleh, 2014).

Human capital management depends on its competencies management and knowledge management (Souleh, 2014). Human capital management responds to the need of creating smart organizations by hiring the right people, giving them the right knowledge and providing them with ways to share that knowledge in order to benefit the entire organization (Fida, 2009). Human capital management is all about ensuring that the enormous potentials provided by people are aligned with the mission and strategic objectives of the business, to maximize their value on behalf of the stakeholders (Finn, 2003). Human capital management is an integrated effort to manage and develop human capabilities to achieve significantly higher levels of performance (Chatzkel, 2004).

\section{Knowledge Resources:-}

A knowledge resource is characterized by completeness it contains all the necessary information elements, interpretations, connections, procedures, and sequences for effective application without further manipulation or analysis (Griffith, 2012). Knowledge resources enable an organization to understand what to do, how to do, and why things work the way they do (Davenport \& Prusak, 2000). As a resource, knowledge can be accumulated, manipulated, disseminated, aggregated, and leveraged to achieve a variety of distinct purposes including either replication or creating increases in the general knowledge stock of an organization (Lengnick-Hall \& Griffith, 2005). Knowledge is awareness, information, or understanding about facts, rules, principles, guidelines, concepts, theories, or processes needed to successfully perform a task (Marrelli, 2001). Knowledge is acquired through learning and experience (Souleh, 2014). The knowledge may be concrete, specific, and easily measurable, or more complex, abstract, and difficult to assess (Lucia \& Lepsinger, 1999). Knowledge of results is the degree to which individuals continuously understand how effectively they are performing the job (Griffin \& Moorhead, 2014).

Knowledge is defined as an intangible resource that consists of interpreted information useful for creating strategic capability. Knowledge is a much richer construct than data or information (Davenport \& Prusak, 2000). Organizational behavior applies the knowledge gained about individuals, groups, and the effect of structure on behavior in order to make organizations work more effectively (Robbins \& Judge, 2013). Knowledge workers are those employees who add value in an organization simply because of what they know (Griffin \& Moorhead, 2014).

\section{Leadership:-}

Leadership according to Kreitner \& Kinicki (2010) is the influence of individuals against others to achieve goals. Leadership is the use of power and influence to direct the activities of its members towards the organization's goals (Colquitt et al., 2011). Schermerhorn (2010) define leadership is the process of influencing others and facilitating business processes of individuals and groups to achieve common goals. McShane \& Glinow (2010) defines leadership is related to influence, motivate, and enable others to contribute to the effectiveness and success of the organization.

Leadership is both a process and a property. As a process, leadership involves the use of non coercive influence. As a property, leadership is the set of characteristics attributed to someone who is perceived to use influence successfully. Strategic leadership is the capability to understand the complexities of both the organization and its environment and to lead change in the organization so as to achieve and maintain a superior alignment between the organization and its environment (Griffin \& Moorhead, 2014). The contemporary leadership theory accentuates on followers' abilities and working skills, encouraging followers to challenge the present systems, and promote rationality and creativity in organizational problem solving (Zagorśek et al., 2016). The literature on effective leadership has suggested that transformational leadership theory and visionary leadership theory has obtained wide acceptance among scholars and practitioners as well (Sashkin, 1988). Some scholars suggest that leadership practice is equated to transformational leadership (Baron \& Kenny, 1986).

\section{Competitive Strategy:-}

Competitive strategy as a broad formula for haw a business is going to compete, what its goals should be and what policies will be needed to carry out those goals (Porter, 1998). Generic strategy typology includes prospectors, defenders, analyzers, and reactors (Miles \& Snow, 1978). Prospectors focus on innovation, creating new markets and enacting uncertain environments. Defenders emphasize cost control in stable environments, concentrating their 
innovative efforts on process issues. Analyzers build a firm foundation in efficiency but continue to pursue incremental innovation through flexibility (Miles and Snow, 1986). Competitive strategy is necessary that small and medium enterprises engaged in activities that lead to a position in the market as organizations that show the quality of their products and services in compliance with certifications in their quality management systems (Contreras \& Silva, 2013).

The discipline of market leaders (1997) described generic competitive strategies or value disciplines are operational excellence, customer intimacy and product leadership. A strategy of operational excellence is ideal for markets where customers value cost over choice, which is often the case for mature, commoditized markets where cost leadership provides a vehicle for continued growth. Leaders in the area of operational excellence are strongly centralized, with strong organizational discipline and a standardized, rule-based operation. Customer intimacy focuses on the needs of the individual customer, true customer intimacy can only arrive through aligning the product development, manufacturing, administrative functions and executive focus around the needs of the individual customer (Sihite \& Simanjuntak, 2015). Customer intimacy as a competitive strategy, the customer intimacy strategy focuses on offering a unique range of customer services that allows for the personalization of service and the customization of products to meet differing customer needs (Ian, 2014).

\section{Competitive Advantage:-}

Competitive advantage is obtained when an organization develops or acquires a set of attributes that allow it to outperform its competitors (Wang, 2014). Competitive advantage means that the firm can produce goods or services that their customers are more valuable than the goods or services produced as a result of their competitors (Saloner et al., 2001). Roger (2010) describes the sources of the competitive advantage such as cost advantage, differentiation advantage and marketing advantage. Competitive advantage consists of capabilities that enable organizations to differentiate itself from its competitors and is the result of important management decisions (Daghfous, 2004). Ambitious companies should always be concerned with how to achieve and sustain a competitive advantage (Elbeltagi et al., 2016). Product innovation and service innovation affect competitive advantage with competition in in foreign countries and needs to be a lifting capacity of supporting industries that can produce parts with quality, at a low cost which are delivered on time (Chamsuk et al., 2015). The way for current business environment has evolved, opportunities for leveraging competitive advantage are transient (Wang, 2014). Culture can only affect competitive advantage through absorptive capacity and innovation (Adriansah \& Afiff, 2015). Competitive advantage is always judge relative to other competitors or the industries average, to obtain a competitive, a firm must either to create more value for customer (value innovations) while keeping its cost comparable to competitors, or it must provide value equivalent to competitors but at lower cost (Sihite \& Simanjuntak, 2015). Competitive advantage is reflected in superior firm performance (sustainable growth) always assess relative to a benchmark, either using competitors or the industry average and maintained over time, competitive advantage is sustainable by measuring profit, people and planet value (Rodrigues, et al., 2012).

The cost leadership strategy focuses on the reduction of cost in productivity or administration to offer a lower price to customers. This strategy refers to how the firm can offer their services at lower fees than others through the ability to control the cost of the firm's administration while increasing productivity. The differentiation strategy promotes creativity in offering services, i.e., diversification. This strategy focuses on five elements consists of marketing, reputation, branding, relationship and innovation (Abidin et al., 2014). Cost leadership means having the lowest perunit cost in the industry, lowest cost relative to your rivals. This could mean having the lowest per-unit cost among rivals in highly competitive industries, in which case returns or profits will be low but, none the less higher than competitors or, this could mean having lowest cost among a few rivals where each firm enjoys pricing power and high profits. Differentiation the product offering of a firm means creating something that is perceived industry wide as being unique (Sihite \& Simanjuntak, 2015). Differentiation means presenting a different product or service which attracts different customers of the market including the competitors' customers (Menguc, 2007). A differentiation strategy create values to the customer through innovative products, superior technology and quality, distinct brands as well as good services, allowing the company to set more prices (Lee \& Lee, 2008).

\section{Theoretical Framework \& Hypothesis:-}

Managing people based on their human capital will allow an organization to optimize knowledge creation, whether of new product, ideas and services or of improvements in business processes (Jyotirmayee \& Mishra, 2010). The resource-based-view accredits human capital as the most important type of resources a firm has (Pfeffer, 1994). 
Zheng et al. (2011) explained that a firm can continually renew their knowledge base through its dynamic capabilities so that it is possible to respond to changing environments.

Figure 1:- Research model

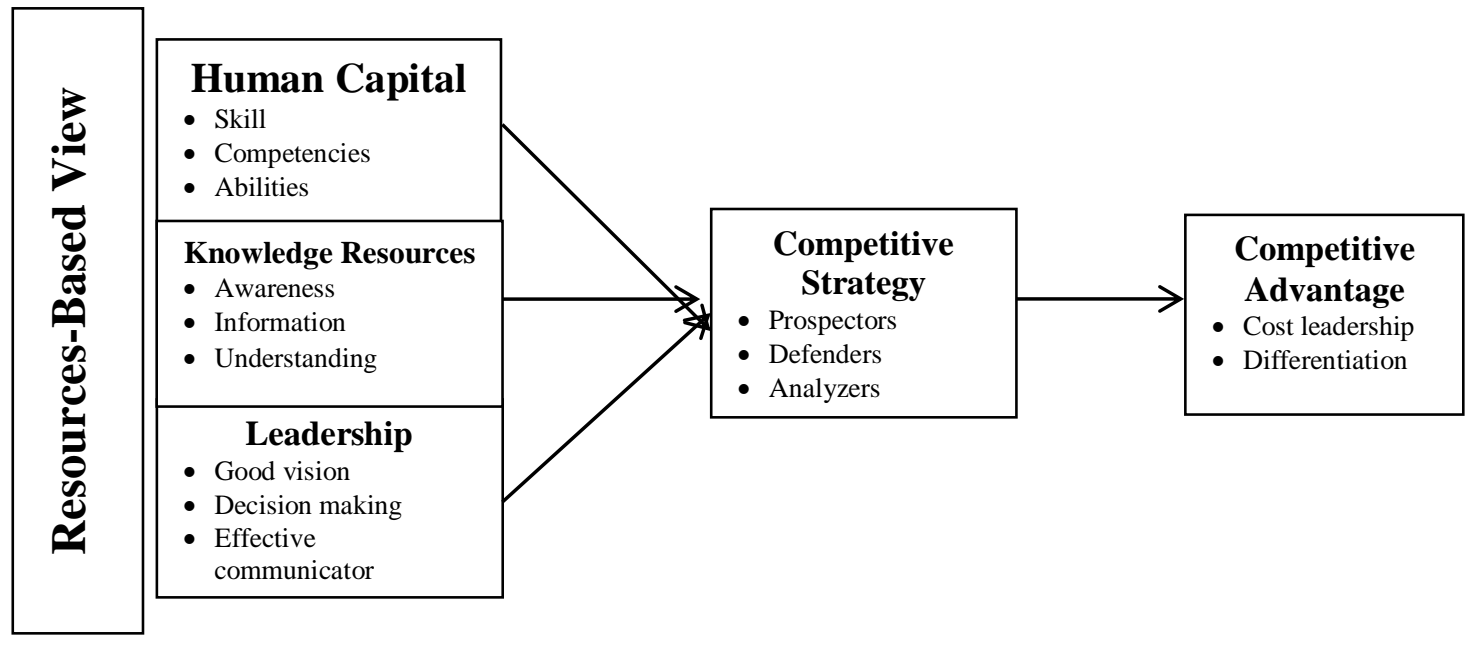

The influence of RBV on competitive advantage has been theoretically proposed. The importance of knowing if such influence exists in practice and determining its magnitude is because of the fact that this effect would provide empirical support for the idea that sustainability is an important source of competitive advantage (Fombrun, 1996).

$\mathrm{H}_{1}$ : Human capital has positive effect on competitive strategy

$\mathrm{H}_{2}$ : Knowledge has positive effect on competitive strategy

$\mathrm{H}_{3}$ : Leadership has positive effect on competitive strategy

$\mathrm{H}_{4}$ : Competitive strategy has positive effect on competitive advantage

\section{Methodology:-}

The main objective of this research was to investigate the influence of RBV indicators consists of human capital, knowledge and leadership on competitive advantage. This study was aimed in various manufacturing industries at West Java, Indonesia that has implemented competitive strategy as a sampling frame. Researches have taken places in various industries such as manufacturing (Kylaheiko \& Sandstrom, 2007). Data analysis for the research was conducted by the researchers using the Lisrel program to assist in the analysis of the variables as well as the application of the structural equation modeling analysis of the causal relationship between variables.

Hair et al. (2010) has said that the size of the sample has to be large enough to be used in the data analysis by the application of the model equations with the structure and the distribution of data. Data was therefore collected from 200 manufacture engaged in industries. Subsequently, simple random sampling was applied for each stratified random sample to the data collected from the surveyed population. Population consists of various manufactures at industrial area in West Java, Indonesia. The data was collected from management through mailed questionnaires distributed through email and face to face conversations. From the target sample of questioners, 168 questioners were completed, 32 were discarded as incomplete. Hence, the final response rate was 84 percent. Data were gathered during the month of January 2016 in industrial area. The statistical results obtained from the questionnaire were analyzed. The final questionnaire comprised five parts included human capital, knowledge, leadership, competitive strategy and competitive advantage. Finally, we decided to conduct our research more specifically in the industries sectors, for several reasons. First, it is a sector in which industrially responsible initiatives are developed and second, this research field helps us avoid the limitation of industrial experiments, since data are obtained in real condition of use. Existing well-established multiple-item 5-point Likert scale were adopted to measure our variables, ranging from 1 (strongly disagree) to 5 (strongly agree). The analyzed problems were solved with the use of mainly quantitative research methods.

\section{Analysis and Result:-}

Table 1 shows that profile of respondents, the result reveals that $56 \%$ of the respondents have 3-10 years of existence. In terms of the number of employee, 50.5\% have big employees around 101-1000. Furthermore, 41\% 
respondents with background activities of automotive manufacture as the most respondents and have effect in survey.

Table 1:- Demographic Respondents.

\begin{tabular}{|l|l|l|l|}
\hline $\begin{array}{l}\text { Demographics } \\
\text { profile }\end{array}$ & Category & No. of respondent & $\%$ \\
\hline Years of existence & Less 3 years & 21 & 12.5 \\
& 3-10 years & 94 & 56 \\
& Over 10 years & 53 & 31.5 \\
\hline Background & Automotive & 69 & 41 \\
activities & Electroni & 53 & 32 \\
& Food \& Beverage & 34 & 20 \\
& Pharmaceutical & 12 & 7 \\
\hline No. of employees & Less 20 & 6 & 3.5 \\
& $21-100$ & 49 & 2 \\
& $101-1000$ & 85 & 9 \\
& Over 1000 & 28 & 50.5 \\
& & & 17 \\
\hline
\end{tabular}

Analysis model shows that research model fits the data. Further, testing the hypothesis indicates an analysis of the influence of the RBV, competitive strategy and competitive advantage. Figure 2 shows the standardized coefficients for the structural relations tested. As can be seen, the goodness of fit indices for the structural model show a good fit and therefore it is feasible to test the proposed hypotheses. $\mathrm{H}_{1}, \mathrm{H}_{2}$ and $\mathrm{H}_{3}$ are supported $\left(\beta_{1}=0.08 ; \beta_{2}=0.21 ; \beta_{3}=\right.$ 0.48 ) as human capital, knowledge resources, leadership dimension in industries on competitive strategy. Human capital, knowledge resources, leadership have a positive direct effect on competitive strategy. $\mathrm{H}_{4}$, is confirmed $\left(\beta_{4}=\right.$ 0.68 ) as the competitive strategy on competitive advantage in industrial. Competitive strategy has a positive direct effect on competitive advantage. These results give empirical support to the idea that the efforts made by manufacture toward industrial will be rewarded by the projection of a positive competitive strategy that will lead to increasing competitive advantage. Therefore, the proposed model is totally supported by the results.

Figure 2:- Structural model estimation
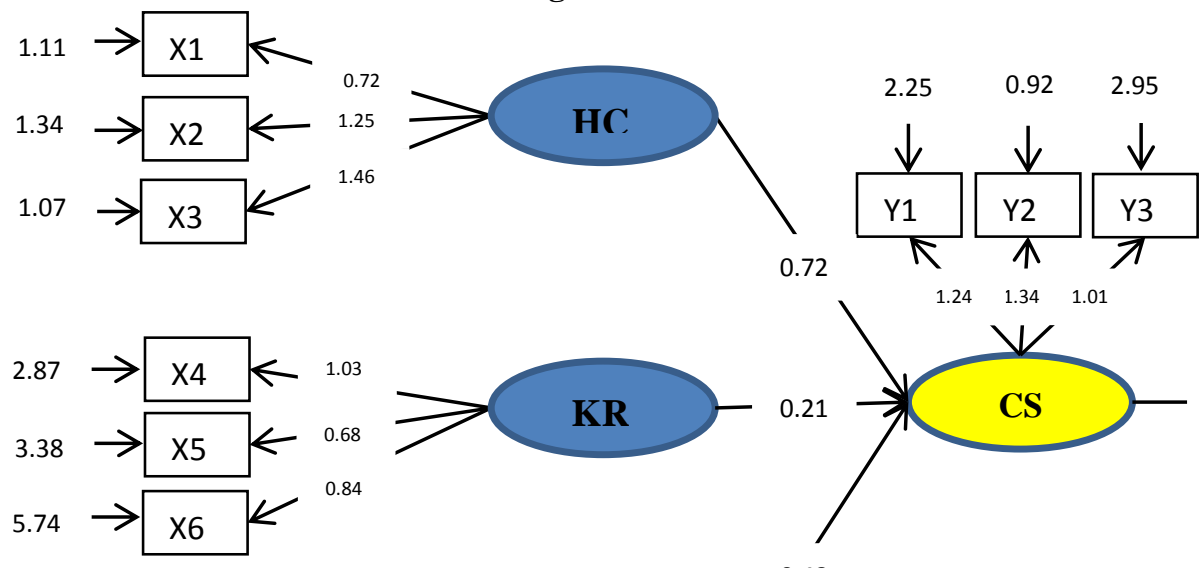

$\begin{array}{lll}1.24 & 1.34 & 1.01\end{array}$
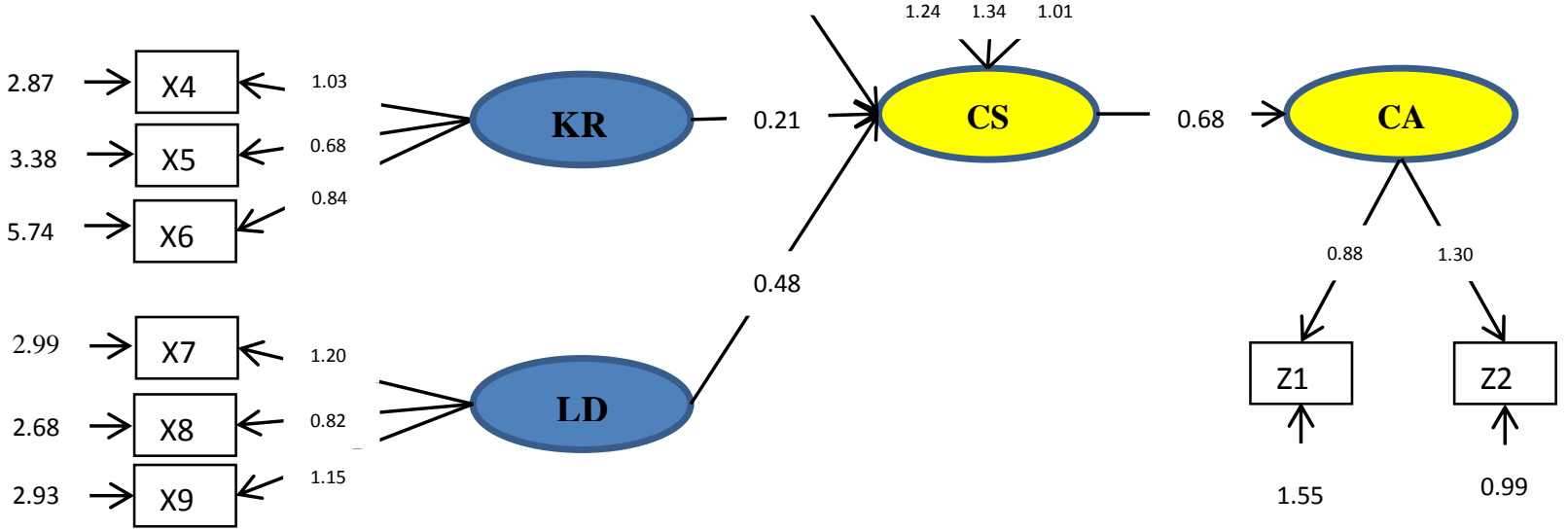

1.55

0.99

The model indicated a confirmatory factor analysis procedure to access all constructs involved in the study. The data are the score of 168 managers in various industries on construct activities. The structural model result shows the achieved stable model fit estimation. The indicators of fit: $\mathrm{Cmin} / \mathrm{df}=4.016(\mathrm{Cmin}=281.15, \mathrm{df}=70)$; $\mathrm{GFI}=0.81$; 
$\mathrm{RMR}=0.37$; NFI $=0.79 ; \mathrm{CFI}=0.83 ; \mathrm{RMSEA}=0.134$. Figure 2 empirically shows that competitive strategy has significant influence $(B=0.68, p=.0000)$ on competitive advantage. These indices suggested that the structural model provided a good fit to the data at hand and yielded a corroborating value for the good model fit.

Table 2:- SEM Result.

\begin{tabular}{|c|c|c|}
\hline Hypotheses Structural Relationship & Standard Coefficient & Contrast \\
\hline Human capital $\rightarrow$ competitive strategy & 0.72 & Accepted \\
\hline Knowledge resources $\rightarrow$ competitive strategy & 0.21 & Accepted \\
\hline Leadership $\rightarrow$ competitive strategy & 0.48 & Accepted \\
\hline Competitive strategy $\rightarrow$ competitive advantage & 0.68 & Accepted \\
\hline
\end{tabular}

\section{Discussion and Conclusions:-}

This study empirically investigates whether there is an effect RBV, competitive strategy and competitive advantage in manufacturing industries. RBV variables are consists of human capital, knowledge resources and leadership. The authors conducted a survey to test the hypotheses and design a SEM to analyze them. RBV has significant effect on competitive strategy. Human capital, knowledge resources and leadership have significant effect on competitive strategy. The result study concluded that competitive strategy has significant effect on competitive advantage. Our empirical evidence supports all the proposed hypotheses. Moreover, this study described that the effect of competitive advantage is mediated by competitive strategy. Such findings are relevant since they add several contributions to the existing strategic management literature. First of all, they provide empirical evidence of RBV has influence on competitive strategy and have impact on competitive advantage.

RBV is a trigger competitive advantage through competitive strategy. Competitive advantage as the impact of the implementation company operation strategy in creating value creation on the products and services produced. Cost leadership and differentiation for products or services into a strategic part in achieving competitive advantage. Competitive strategy becomes part of the corporate strategy led to increased productivity and performance. Resource-based view favor ability and capabilities in encouraging better corporate performance. It is a main assumption in the resources-based view of the firm that only firms with certain resources, network links and characteristics will achieve competitive advantages through innovation and therefore achieve superior performance (Camisón \& Villar-Lopéz, 2014). Since previous works have essentially focused on the role of increasing business performance, this study adds to our understanding of the effect competitive strategy and competitive advantage. By providing relevant information to stakeholder about the industries, the identity of industries based on competitive strategy and competitive advantage. The RBV indicates that organizations should focus on combinations of rare resources that promote an organization's competitive advantage (Newbert, 2008). Firms renew their resource base upon dynamic capabilities approach and which deploy relevant capabilities as dynamic capabilities hold the potential for a sustained competitive advantage especially in a turbulent environment (Breznik \& Lahovnik, 2016).

The present research focused on the concepts of RBV, competitive strategy, and competitive advantage at various manufacturing industries. Our findings suggest that RBV aspects are key components, richer, and in-depth views of this concepts between competitive strategy and competitive advantage. Including this variable in our model, future studies would contribute to a superior explanatory power to better understanding of the nature in competitive strategy and competitive advantage. In this sense, previous studies show that to have a more coherent and stable competitive strategy. This led us to a RBV of the firm, which states that the competitive advantage of the firm lies primarily in the application of a bundle of valuable, tangible, or intangible resources at the firm's disposal (Barney, 2001). Moreover, the current study has been conducted with consumers in manufacturing industries in West Java, Indonesia and it is not clear in how far the findings can be generalized to other sectors, stakeholders or countries. Future research could extend this research by including different stakeholder expectations of RBV, competitive strategy and competitive advantage. Therefore, it would be interesting to replicate this study but considering various stakeholders to ensure that our results are extrapolated to all target business such as e-commerce, real estate, oil and gas, agricultures.

\section{Acknowledgments:-}

This research was funded by the Indonesia Endowment Fund for Education (LPDP) provided by the Indonesian Finance Ministry. 


\section{References:-}

1. Abidin, N. Z., Adros, N. A. and Hassan, H. (2014): Competitive Strategy and Performance of Quantity Surveying Firms in Malaysia. Journal of Construction in Developing Countries, 19(2): 15-32.

2. Adriansah, A. and Afiff, A. Z. (2015): Organizational Culture, Absorptive Capacity, Innovation Performance and Competitive Advantage: An Integrated Assesment in Indonesian Banking Industry. The South East Asian Journal of Management, 9(1): 70-86.

3. Angela, B. and Michael, A. (2007): Human capital management. London: Kogan Page.

4. Angelmar, R. (1990): Product innovation: a tool for competitive advantage. European Journal of Operational Research, 47(2): 182-189.

5. Barney, J. B. W. and Ketchen, D. J. (2001): The Resource-Based View of the Firm: Ten years after 1991. Journal of Management, 27: 625-641.

6. Baron, R. M. and Kenny, D. A. (1986): The moderator-mediator variable distinction in social psychological research: Conceptual, strategic, and statistical considerations. Journal of Personality and Social Psychology, 51(6): 1173-1182.

7. Baumane-Vitolina, I. and Cals, I. (2013): Theoretical Framework For Using Resource Based View in the Analysis of SME Innovations. European Scientific Journal, 1: 174-182.

8. Bontis. N, (1999): Managing organizational knowledge by diagnosing intellectual capital: framing and advancing the state of the field. International Journal of Technology Management, 18(5-8): 433-62.

9. Breznik, L. and Lahovnik, M. (2016): Dynamic Capabilities and Competitive Advantage: Findings From Case Studies. Journal of Management, 21: 167-185.

10. Camisón, C. and Villar-Lopéz, A. (2014): Organizational Innovation as an Enabler of Techno-logical Innovation Capabilities and Firm Performance. Journal of Business Research, 67: 2891-2902.

11. Cao, D., Berkeley, N. and Finlay, D. (2014): Measuring Sustained Competitive Advantage From Resourcebased View: Survey of Chinese Clothing Industry. Journal of Sustainable Development, 7(2): 89-104.

12. Chamsuk, W., Phimonsathien, T. and Fongsuwan, W. (2015): Research and Development (R\&D) Capabilities and Innovation Capability That Affect the Enterprise Competitive Advantage in The Thai Automotive Parts Industry: SEM Approach. International Journal of Arts \& Sciences, 08(02): 441-457.

13. Chao, R. (2014): Innovation Strategies of Local Intermediary Organizations for Environmental Protection: A Case Study of Green Island, Taiwan. The International Journal of Organizational Innovation, 7(2): 87-97.

14. Chatzkel, J. L. (2004): Human capital: the rules of engagement are changing. Lifelong learning in Europe, 9(3): $139-145$.

15. Coff, R. W. (2002): Human likelihood of capital, shared expertise, and the impasse on corporate acquisitions. Journal of Management, 28: 107-128.

16. Colquitt, J. A., LePine, J. A. and Wesson, M. J. (2011). Organizational Behavior, Improving Performance and Commitment in the Workplace, 2nd Edition. New York: Mc-Graw Hill.

17. Contreras, O. A. R. and Silva, F. A. B. (2013): Competitive Strategy To Achieve ISO 9001 Certification in Small and Medium Supply Enterprises in Ciudad Juarez, Chihuahua, Mexico. European Scientific Journal, 9(28): 133-143.

18. Daghfous, A. (2004): Absorptive Capacity and The Implementation of Knowledge Intensive Best Practices. S.A.M Advanced Management Journal, 69(2).

19. Davenport, T. H. and Prusak, L. (2000): Working Knowledge: How Organizations Manage What They Know. Boston: Harvard Business School Press.

20. Elbeltagi, I., Hamad, H., Moizer, J. and Abou-Shouk, M. A. (2016): Levels of Business to Business ECommerce Adoption and Competitive Advantage in Small and Medium-Sized Enterprises: A Comparison Study Between Egypt and the United States. Journal of Global Information Technology Management, 19(1): 625.

21. Fauska, P., Kryvinska, N.and Strauss, C. (2013): The role of e-commerce in B2B markets of goods and services. International Journal of Services, Economics, and Management, 5(1-2): 41-71.

22. Fida, A. (2009): Human Capital Management, What does it Really Mean. Proceedings of the European Conference on Intellectual Capital, in Holland University of Applied Sciences, Haarlem, Netherlands, 28-29 April.

23. Finn, R. (2003): Human-capital management (HCM): a three-letter acronym too far for HR or the way to get the people agenda on to that of the board. Human Resource Management International Digest, 11(5): 2-4.

24. Fombrun, C. J. (1996): Reputation, realizing value from corporate image. Boston: Harvard Business School Press. 
25. Griffin, R. W. and Moorhead, G. (2014): Organizational Behavior: Managing People and Organizations, Eleventh Edition. South-Western: Cengage-Learning.

26. Griffith, R. J. (2012): Knowledge Flow: Exploring The Links Between Knowledge Resources, Organizational Actions, and Performance, Dissertation: The University of Texas.

27. Hair, J., Black, W. C., Babin, B.J. and Anderson, R. E. (2010): Multivariate analysis, 7th edition. New Jersey: Pearson Education International.

28. Howorth, C., Rose, M., Hamilton, E. and Westhead, P. (2010): Family firm diversity and development: An introduction. International Small Business Journal, 28(5): 437-451.

29. Ian, R. (2014): Innovation and creativity in organizations: A review of the implications for training and development. Report Information from ProQuest.

30. Jain, S. K. and Ahuja, I. S. (2012): An Evaluation of ISO 9000 Initiatives in Indian Industry For Enhanced Manufacturing Performance. International Journal of Productivity and Performance Management, 61(7): 778804.

31. Jules, M. N. D. and Fondo, S. (2012): The Effects of Human Capital on Agricultural Productivity and Farmer's Income in Cameroon. International Business Research, 5(4): 149-159.

32. Jyotirmayee, C. and Mishra, B. B. (2010): Theoretical and Empirical Investigation of Impact of Developmental HR Configuration on Human Capital Management. International Business Research, 3(4): 181-186.

33. Kash, B. A., Spaulding, A., Gamm, L. D. and Johnson, C. E. (2014): Healthcare Strategic Management and the Resource Based View. Journal of Strategy and Management, 7(3): 251-264.

34. Kaveh, D., Bamipour, E. M. and Far, M. S. (2015): The Relationship between Knowledge Management and Competitive Advantage: A Case Study in Small and Medium-Sized Companies in the Packaging Industry of Khorasan Razavi. European Online Journal of Natural and Social Sciences, 4(1): 650-659.

35. Kreitner, R. and Kinicki, A. (2010): Organizational Behavior, Key Concepts, Skills \& best Practice, 9th Edition. New York: McGraw-Hill.

36. Kuratko, D. F., Ireland, R. D., Covin, J. G. and Hornsby, J. S. (2005): A Model of Middle-Level Managers Entrepreneurial Behaviour. Entrepreneurship Theory and Practice, 29(6): 699-716.

37. Kylaheiko, K. and Sandstrom, J. (2007): Strategic Options-based Framework for Management of Dynamic Capabilities in Manufacturing Firms. Journal of Manufacturing Technology Management, 18(8): 966-984.

38. Laursen, R. J., Cavusgil, T. S. and Zhao, Y. (2012): Learning Orientation, Firm Innovation Capability, and Firm Performance. Industrial Marketing Management, 31: 15-524.

39. Lee, Y. K., Lee, C. K., Lee, S. K. and Babin, B. J. (2008): Festival scapes and patrons' emotions, satisfaction, and loyalty. Journal of Business Research, 61(1): 56-64.

40. Lengnick-Hall, C. A. and Griffith, R. J. (2005): Disentangling Knowledge Flow, Knowledge Transfer and Knowledge Sharing: Steps Toward Construct Clarity. Paper presented at the National Academy of Management Proceedings, Honolulu, Hawaii.

41. Lucia, A. and Lepsinger, R. (1999): The art and science of competency models: Pinpointing critical success factors in organizations. San Francisco: Jossey-Bass/Pfeiffer.

42. Marta-Christina, S. (2000): Intangible assets and intellectual capital as key factors of romania's convergence. Available at www.moyak.com/knowledge-based-economy.

43. Marrelli, A. F. (2001): Introduction to competency modeling. New York: American Express.

44. McShane, S. L. and Glinow, M. A. N. (2010): Organizational Behavior: Emerging Knowledge And Practice For The Real World, 5th Edition. New York: McGraw-Hill, 2010.

45. Menguc, B., Auh, S. and Shih, E. (2007): Transformational leadership and market orientation: implicationsfor the implementation of competitive strategies and business unit performance. Journal of Business Research, 60(4): 314-21.

46. Miles, R. E. and Snow, C. C. (1978): Organizational Strategy, Structure, and Process. New York: West.

47. Miles, R. E. and Snow, C. C. (1986): Organizations: new concepts for new forms. California Management Review, 18(3): 62-73.

48. Newbert, S. L. (2008): Value, rareness, competitive advantage, and performance: a conceptual level empirical investigation of the resource-based view of the firm. Strategic Management Journal, 29(7): 745-768.

49. Pfeffer, J. (1994): Competitive advantage through people: unleashing the power of the workforce. Boston: Harvard Business School Press.

50. Porter, M. (1998): Competitive Strategy: Techniques for Analyzing Industries and Competitors. New York: The Free Press.

51. Robbins, S. P. and Judge, T. A. (2013): Organizational Behavior, $15^{\text {th }}$ Edition. New Jersey: Prentice Hall.

52. Rocha, R. (1999): Estrategia Competitiva Para Empresas: Guia Practica. Mexico: Trillas. 
53. Rodrigues, L. C., Maccari, E. A. and Lenzi, F. C. (2012): Innovation strategy for business to business market. International Business Research, 5(2).

54. Roger, B. J. (2010): Market-Based Management: Strategies for Growing Customer Value and Profitability. New Jersey: Prentice Hall.

55. Saloner, G., Andrea, S. and Joel, P. (2001): Strategic Management. New York: John Wiley.

56. Sashkin, M. (1988): The visionary leader. In Charismatic Leadership: The Elusive Factor in Organizational Effectiveness, J. A. Conger and R. A. Kanungo, Eds., San Francisco: Jossey-Bass, 122-160.

57. Schermerhorn, J. R. (2010): Introduction to Management, 10th Edition. New Jersey: John Willey \& Sons, 2010.

58. Sihite, M. and Simanjuntak, A. (2015): The Competitive Strategy in Green Building for Indonesian Stakeholder's. International Journal of Innovation, Management and Technology, 6(1): 8-15.

59. Souleh, S. (2014): The impact of Human Capital Management on the Innovativeness of research Center: The Case of Scientific Research Centers in Algeria. International Journal of Business and Management, II(4): 80-96.

60. Szymaniec-Milicka, K. (2014): Resource-based View in Strategic Management of Public Organizations - A Review of The Literature. Journal of Management, 18(2): 19-30.

61. Wang, H. (2014): Theories for Competitive Advantage. In H. Hasan (Eds.), Being Practical with Theory: A Window into usiness Research, 33-43.

62. Zagorśek, H., Stough, S. J. and Jaklic, M. (2006): Analysis of the Leadership Practice Inventory in the item response theory framework. International Journal of Selection and Assessment, 14(2): 180-191.

63. Zheng, S., Zhang, W., Wu, X. and Du, J. (2011): Knowledge-based dynamic capabilities and innovation in networked environments. Journal of Knowledge Management, 15(6): 1035-1051. 